\title{
PAWEŁ PODESZWA \\ »Temu, który nas miłuje« (Ap 1,5). Miłość Chrystusa do Kościoła w świetle wybranych tekstów z Apokalipsy św. Jana
}

Papież Franciszek w bulli Misericordiae vultus, ogłaszającej Nadzwyczajny Jubileusz Miłosierdzia, zachęca nas do ciągłego zgłębiana wielkiej tajemnicy Bożej miłości: Potrzebujemy nieustannie kontemplować tę tajemnice mitosierdzia. Jest ona dla nas źródtem radości, ukojenia i pokoju. Jest warunkiem naszego zbawienia. Miłosierdzie: to jest stowo, które objawia Przenajświętsza Trójcę. Miłosierdzie: to najwyższy i ostateczny akt, w którym Bóg wychodzi nam na spotkanie. Miłosierdzie: jest podstawowym prawem, które mieszka w sercu każdego człowieka, gdy patrzy on szczerymi oczami na swojego brata, którego spotyka na drodze życia. Miłosierdzie: to droga, która łaczy Boga z człowiekiem, ponieważ otwiera serce na nadzieję bycia kochanym na zawsze, pomimo ograniczeń naszego grzechu' ${ }^{1}$ Istotnym sposobem owej kontemplacji tajemnicy miłosierdzia jest medytowanie słowa Bożego, poprzez które nie tylko mamy możliwość usłyszeć bicie Bożego serca, ale przyjęte słowo formuje i uzdalnia nas do stylu życia ucznia Jezusa, naznaczonego miłosierną miłością względem innych. We wspomnianym dokumencie papieskim Franciszek wskazuje wiele tekstów biblijnych, które odsłaniają tajemnicę Bożego miłości i ukazują jej konsekwencje dla życia wyznawców Chrystusa.

W niniejszym artykule proponuję refleksję nad tajemnicą Bożej miłości, objawionej i urzeczywistnionej w Jezusie Chrystusie, która bezpośrednio odnosi się do wspólnoty Kościoła. Analizowane teksty zostaną zaczerpnięte z ostatniej

Paweł P O D E S Z W A, ks. dr hab. nauk teologicznych, profesora nadzwyczajny UAM w Zakładzie Nauk Biblijnych Wydziału Teologicznego Uniwersytetu im. Adama Mickiewicza w Poznaniu, e-mail: podpaw@amu.edu.pl.

\footnotetext{
${ }^{1}$ Fr a n c i s z e k: Misericordiae vultus. Wrocław 2015 s. 4 (n. 2).
} 
księgi Nowego Testamentu, jaką jest Apokalipsa św. Jana, określana niekiedy jako synteza catego Pisma Świętego ${ }^{2}$. Będąc księga napisana w Kościele i dla $K_{\text {Kósioła }}^{3}$, opisuje wspólnotę $\mathrm{w}$ jej różnorodnych wymiarach ${ }^{4}$. Jednym z istotnych rysów eklezjologii Apokalipsy jest przekonanie, że Kościół to wspólnota zrodzona z miłości Jezusa, podtrzymywana, umacniana i prowadzoną ciągle tą samą Chrystusową miłością. Wskazują na to przede wszystkim te teksty Apokalipsy, które wprost mówią o miłości Jezusa do Kościoła, a ideę te wyrażają przy pomocy dwóch charakterystycznych czasowników tradycji Janowej ${ }^{5}$, jakim są $\dot{\alpha} \gamma \alpha \pi \alpha \dot{\alpha} \omega$ oraz $\phi \iota \lambda \lambda^{\prime} \omega$. Choć czasowniki te nie występują często w Apokalipsie (odpowiednio cztery razy: 1,$5 ; 3,9 ; 12,11 ; 20,9$ oraz dwa razy: 3,$19 ; 22,15)$, to jednak w większości ${ }^{6}$ pojawiają się $\mathrm{w}$ passusach, które opisują relację Chrystusa i wspólnoty Kościoła $(1,5 ; 3,9.19 ; 20,9)$. Prześledzimy teraz wskazane fragmenty, aby lepiej poznać tajemnicę Chrystusowej miłości do Kościoła oraz dostrzec jej konkretne przejawy w życiu wspólnoty oraz praktyczne konsekwencje dla współczesnego wyznawcy Jezusa.

\section{I. »Temu, który nas miłuje" « $(1,5)$}

Po prologu Księgi (1,1-3) rozpoczyna się pierwsza część Apokalipsy, którą stanowi siedem listów do Kościołów Azji Prokonsularnej (2,1-3,22), poprzedzonych początkowym dialogiem liturgicznym $(1,4-8)$ oraz wizją wstępną $(1,9-20)$. $\mathrm{W}$ obrębie dialogu liturgicznego, wypowiadanego na przemian przez lektora i zgromadzenie ${ }^{7}$ pojawia się pierwsze określenie, które odnosi się wprost do Jezusa i wyraża Jego miłości do Kościoła. Dialog rozpoczyna się od pozdrowienie

\footnotetext{
${ }^{2}$ P. O stański: Objawienie Jezusa Chrystusa. Praktyczny komentarz do Apokalipsy. Ząbki 2005 s. 9.

${ }^{3}$ W. P o p i e le w s k i: Błogostawieni, którzy sa wezwani na ucztę godów Baranka $($ Ap 19,9). Kościół w Księdze Apokalipsy. „Verbum Vitae”. T. 6: 2004 s. 169.

${ }^{4}$ Zob. D. K o t e c k i: Kościót w świetle Apokalipsy św. Jana. Częstochowa 2009; P. P o d e s z w a: Wspólnota Kościoła w świetle Apokalipsy św. Jana. W: Mowa światyni. Pod redakcją R. D u b l a ń s k i e g o. Wrocław 2012 s. 55-69.

${ }^{5}$ Toczy się dyskusja egzegetów na temat znaczenia tych dwóch czasowników w tradycji Janowej. Dzisiaj coraz częściej uznaje się, że oba czasowniki są synonimami. Syntetycznie problem użycia obu form oraz dyskusję komentatorów przedstawia P. Talaga: L'amore a Cristo, fondamento del ministero pastorale di Pietro nel Vangelo secondo Giovanni (21,15-23). Dissertatio ad Lauream in Facultate S. Theologiae apud Pontificiam Universitatem S. Thomae in Urbe. Roma 2003, s. 71-89.

${ }^{6}$ Tylko w 12,11 mowa o chrześcijanach, którzy „nie umiłowali swego życia - aż do śmierci”, natomiast w 22,15 wspomina się o tych, którzy pozostają na zewnątrz Miasta, określenie jako „kochający i czyniący kłamstwo”.

${ }^{7}$ Na temat struktury dialogu, zob. D. K o t e c k i: Jezus a Bóg Izraela w Apokalipsie św. Jana. Toruń 2013 s. 46-47.
} 
skierowanego przez lektora do wspólnoty, zgromadzonej na liturgii ${ }^{8}$ : „Laska wam i pokój od Tego, który jest, który był i który przychodzi, i od siedmiu duchów, które są przed Jego tronem, i od Jezusa Chrystusa, Świadka wiernego, Pierworodnego umarłych i Władcy królów ziemi”" $(1,4-5 a)^{9}$. Odpowiedzią zgromadzenia jest pierwsza doksologia Apokalipsy ${ }^{10}$ : „Temu, który nas miłuje i który uwolnił nas od grzechów naszych we krwi swojej oraz uczynił nas królestwem, kapłanami dla Boga, swego Ojca, Jemu chwała i panowanie na wieki wieków. Amen" (1,5b-6).

Pierwsze określenie, które odnosi się do „Jezusa Chrystusa, Świadka wiernego, Pierworodnego umarłych i Władcy królów ziemi”, stanowi imiesłów czasu

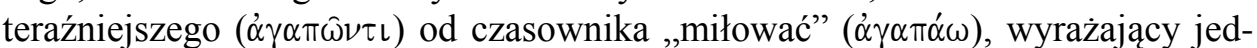

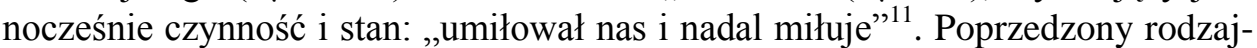
nikiem określonym $(\tau \hat{)})$ może występować w funkcji rzeczownikowej („osoba, która kocha”) i przymiotnikowej („,kochający”). A zatem w pierwszych słowach, zgromadzony na liturgii Kościół uwielbia osobę Jezusa i Jego zbawcze dzieło, eksponując miłość Chrystusa jako fundament wszystkiego. Jest ona siłą działającą i napędową Jego zbawczej misji ${ }^{12}$.

Miłość Jezusa jest ukierunkowana na „,nas” (i் w bierniku odnosi się w oczywisty sposób do wspólnoty, która wcześniej była adresatem pozdrowienia wstępnego, to znaczy siedmiu wspólnot z Azji Mniejszej (Efez, Smyrna, Pergamon, Tiatyra, Sardes, Filadelfia, Laodycea), które, zgodnie z symbolizmem arytmetycznym, oznaczają Kościół wszystkich miejsc i czasów. Jak słusznie zauważa ks. Kotecki: W dialogu liturgicznym początkowym te Kościoly staja się konkretnym zgromadzeniem liturgicznym zebranym na stuchaniu słowa i to właśnie one wyrażaja przekonanie całego Kościoła o nieu-

\footnotetext{
${ }^{8} \mathrm{Na}$ temat liturgicznego charakteru Apokalipsy, zob. D. K o te c k i: Duch Święty w zgromadzeniu liturgicznym w świetle Apokalipsy św. Jana. Warszawa 2006. W monografii Autor omawia

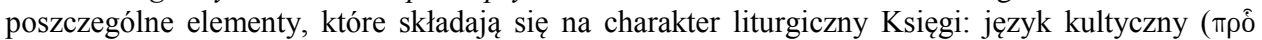

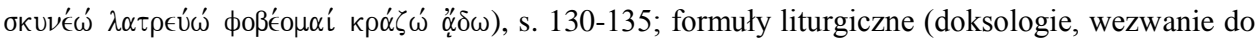
chwalenia, modlitwy dziękczynienia, formuła „godzien jesteś” oraz „amen” i „alleluja”, Trishagion, „Maranatha”, hymny), s. 136-154; miejsca i przedmioty związane z liturgią (świątynia, namiot, arka, siedem złotych świeczników, ołtarz, kadzielnica, szklane morze, instrumenty muzyczne, złote czasze, księga, ubiór Jezusa), s. 154-169; czynności liturgiczne (opłukiwanie szat, pieczętowanie, wybielanie we krwi Baranka), s. 169-172; obecność dialogów liturgicznych (zwłaszcza początkowy 1,4-8 oraz końcowy 22,6-21), s. 183-196; błogosławieństwa w 1,3 dla czytającego i słuchających słowa proroctwa, s. 176-178.

${ }^{9} \mathrm{Na}$ temat tego pozdrowienia, zob. P. P ode s z w a: Paschalna pamięć o Jezusie. Studium

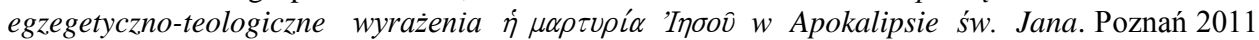
s. $140-179$.

${ }^{10}$ Na temat doksologii w Apokalipsie, zob. P. P ode s z w a: Doksologie Apokalipsy jako model modlitwy uwielbienia, „Verbum Vitae”. T. 22: 2012 s. 155-184.

${ }^{11}$ F. S i e g: Apokalipsa św. Jana. Listy do siedmiu Kościołów (Ap 1-3). Pelplin ${ }^{2} 2009$ s. 28.

${ }^{12}$ P. P o d e s z w a: Paschalna pamięć. dz. cyt. s. 179.
} 
stannie trwającej miłości Jezusa (stąd imiesłów czasu teraźniejszego) ${ }^{13}$. Można zatem powiedzieć, że wspólnota ma pełną świadomość, że została zrodzona z miłości Jezusa i trwa dzięki tej samej miłości, stąd Jezusa nazywa „Miłującym". To nowe Imię Jezusa przywołuje w pamięci wiele fragmentów Ewangelii Janowej, gdzie mowa o Jego miłości do przyjaciół i uczniów $(11,5 ; 13,1 ; 15,3)^{14}$. Jezus jest świadomy, że Jego miłość do człowieka jest odwzorowaniem miłości Ojca do Niego samego. W 15,9 stwierdza: ,jak mnie umiłował Ojciec, tak i Ja was umiłowałem. Trwajcie w miłości mojej”. W wypowiedzi tej Jezus objawia apogeum swojej miłości do uczniów. Jest to tego rodzaju miłość, jaka Ojciec umiłowat Syna. W miłości Jezusa do wierzacych widzimy najwyższy wyraz miłości Boga do ludzi (por. 13,1; 19,30) ${ }^{15}$. Warto też zwrócić uwagę, że czasowniki są użyte w aoryście nazywanym przez komentatorów aoristus complexivus, który wskazuje na miłość doskonałą, istniejącą od zawsze i pozostającą na zawsze. Jezus jest zatem miłującym na zawsze miłością Boga, doskonałą i pełną. „Umi-

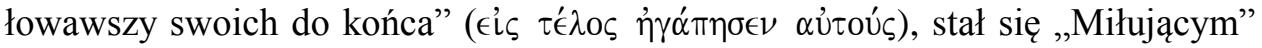
$(\tau \hat{\jmath} \alpha \hat{\alpha} \gamma \alpha \pi \hat{\omega} \nu \tau \iota)$ i wzorem do naśladowania przez swoich uczniów: „trwajcie W miłości mojej” $(15,9)$; „to jest moje przykazanie, abyście się wzajemnie miłowali, jak ja was umiłowałem" $(15,12)$. Miłość Jezusa jest miarą miłości między Jego uczniami, staje się ich nowym przykazaniem: „Daję wam nowe przykazanie, abyście się wzajemnie miłowali. Podobnie jak Ja was umiłowałem, tak i wy będziecie miłować jeden drugiego" $(13,34)$. Tylko dzięki tej właśnie miłości uczniowie zostaną rozpoznani jako prawdziwi naśladowcy Jezusa: „po tym wszyscy poznają, że jesteście moimi uczniami, jeśli będziecie się wzajemnie miłowali" $(13,35)$.

Miłość Chrystusa ukierunkowana na wspólnotę uczniów wyraża się w Jego zbawczej śmierci na krzyżu. Mówią o tym kolejne wyrażenia analizowanej doksologii: „który uwolnił nas od grzechów naszych we krwi swojej oraz uczynił nas królestwem, kapłanami dla Boga, swego Ojca". W powyższych sformułowaniach zostaje przywołane misterium paschalne (,we krwi swojej”), którego skutkiem jest przywrócenie jedności z Bogiem przez przebaczenie grzechów (,uwolnił nas od grzechów naszych") oraz uczynienie z chrześcijan pośredników między Bogiem a światem (,kapłani”), zdolnych do składania Bogu w Jezusie pochwalnej ofiary ${ }^{16}$ i jednocześnie „królów”, którzy mają udział w zwycięstwie, a zatem w Jego zmartwychwstaniu i panowaniu na wieki ${ }^{17}$. Zgromadzenie liturgiczne wielbi Chrystusa za wielkie dzieło zbawienia, które dzięki miłości Boga staje się

${ }^{13}$ Zob. D. K o t e c k i: Jezus, dz. cyt. s. 86.

${ }^{14}$ Zob. P. P o d e s z w a: Paschalna pamięć, dz. cyt. s. 179-180.

${ }^{15}$ S. M ę d a 1 a: Ewangelia wedtug świętego Jana. cz. II. Częstochowa 2010 s. 117.

${ }^{16}$ Zob. P. O s t a ń s k i: Objawienie, dz. cyt. s. 73-74.

${ }^{17}$ Szerzej na ten temat, zob. P. P o d e s z w a: Paschalna pamięć, dz. cyt. s. 182-197; D. K o t e c k i: Jezus, dz. cyt. s. 88-105. 
udziałem człowieka. Jednocześnie wyznaje przekonanie, że jedynie dzięki ofierze Jezusa $\left(7,14\right.$ : „we krwi Baranka" ${ }^{\text {, }}$ ) możliwe jest uwalnianie z grzechów, którego nieustannie Kościół potrzebuje. Jednocześnie wspólnota ma świadomość tego niezwykłego daru. Sformułowanie z Apokalipsy przypomina to z Ef 5,25, gdzie mowa, że „Chrystus umiłował Kościół i wydał za niego samego siebie”, stąd zachęta w Ef 5,2: „postępujcie w miłości na wzór samego Chrystusa, który nas umiłował i samego siebie wydał za nas jako dar i ofiarę dla Boga jako miłą woń”. Podobnie w Gal 2,20 apostoł Paweł stwierdza: „Chrystus umiłował mnie i samego siebie wydał za mnie". Jak można wnioskować z przytoczonych tekstów miłość Jezusa jest związana z Jego zbawczą ofiarą i w niej najpełniej się wyraża. Wspólnota Kościoła jest zatem wezwana, aby zawsze pamiętała, że istnieje i żyje dzięki miłości Chrystusa.

\section{II. »Przekonają się, że ciebie umiłowałem« $(3,9)$}

Kolejne stwierdzenie wprost odnoszące się do miłości Jezusa do Kościoła odnajdujemy w Liście do Kościoła w Filadelfii (3,7-13). Miasto to leżało w Lidii, około 45 kilometrów na południowy wschód od Sard, a zostało założone w II wieku przed Chr. przez kolonistów z Pergamonu. Filadelfia stała się „Atenami Wschodu", gdyż propagowała kulturę grecką w Lidii i na sąsiadujących terenach ${ }^{19}$. Nie wiadomo dokładnie w jaki sposób chrześcijaństwo dotarło do miasta. Prawdopodobnie pierwsi wyznawcy Jezusa wywodzili się ze środowiska żydowskiego ${ }^{20}$, gdyż w Liście odnajdujemy aluzje do napięć między chrześcijanami, a tymi którzy nie uwierzyli (3,9: „ludzie z synagogi Szatana”). Czytając Apokalipsę rozumiemy jednak, że wspólnota w Filadelfii, choć znikoma i bezbronna (3,8: „masz sił niewiele”) została bardzo wysoko oceniona przez Chrystusa. Właściwie jest to jeden z tych Listów, w którym nie ma żadnego upomnienia czy nagany (podobnie w przypadku Listu do Kościoła w Smyrnie, 2,8-11), a obietnica zwycięstwa jest podwójna $(3,10$ : „zachowam cię w godzinie próby, która nadciąga na świat” oraz 3,12: „zwycięzcę uczynię filarem w świątyni mo-

18 Zob. P. P ode s zwa: Wyprali swoje szaty $i$ wybielili je we krwi Baranka (Ap 7,14). Chrzest wedlug Apokalipsy świętego Jana. „Studia Bydgoskie”. T. 7: 2013 s. 33-54.

${ }^{19}$ Zob. P. O stańs ki: Objawienie..., dz. cyt. s. 117-118, szerzej na temat Filadelfii, zob. R. T k a c z: Listy do siedmiu Kościołów (Ap 2,1-3,22). Studium historyczno-egzegetyczne. Warszawa 2003 s. 305-316.

${ }^{20}$ Choć brakuje jednoznacznych świadectw potwierdzających istnienie wspólnoty żydowskiej w mieście, to jednak, jak zauważa R. T k a c z: Listy, dz. cyt. s. 313 w istocie diaspora żydowska $w$ Filadelfii, podobnie jak $i w$ wielu ośrodkach handlowych położonych na szlakach komunikacyjnych Azji Mniejszej, musiała być raczej znaczna, tym bardziej że leżace w pobliżu Filadelfii miasto Sardes, oddalone tylko o $45 \mathrm{~km}$, było wielkim ośrodkiem żydowskiej diaspory. Podobnie, E. J a n u s: Grzechy Kościołów Apokalipsy i Jezusowe sposoby ich przezwyciężenia (Ap 2-3). Kraków 2013 s. 37. Zdaniem natomiast F. S i e ga: Apokalipsa, dz. cyt. s. 125 prawdopodobnie Kościót w Filadelfii sktadat się w większości z nawróconych pogan. 
jego Boga i już nie wyjdzie na zewnątrz). Jak zauważa ks. Ostański: Kiedy islam zalat Azję Mniejsza, wszystkie miasta Apokalipsy upadty. Jedynie Filadelfia zachowata niezawistość. Poprzez wieki pozostawała wolnym greckim miastem chrześcijańskim $i$ ostatnim bastionem chrześcijaństwa w Azji. Upadła dopiero w XIV w., ale do dzisiaj mieszkaja tam chrześcijanie wraz ze swoim biskupem. Inne miasta Apokalipsy, $z$ wyjątkiem Smyrny, zamienity się $w$ ruiny, a w Filadelfii (dziś Alesehir) wciąż trwa i żyje Kościót ${ }^{21}$.

Po autoprezentacji, w której Chrystus określa siebie jako „Święty i Pełen Prawdy, który ma klucz Dawida” (3,7), Jezus docenia wierność wspólnoty: „dochowałeś wierności mojemu słowu i nie zaparłeś się mnie" $(3,8)$. Zapowiada także posłanie do wspólnoty ludzi ,z synagogi Szatana, którzy twierdzą, że są Żydami, a kłamią, bo nimi nie są" (3,9). Jednocześnie Jezus obiecuje, iż On sam sprawi, że „przyjdą i będą się tobie kłaniać do stóp i przekonają się, że ciebie umiłowałem” $(3,9)$. Kim są ludzie z „synagogi Szatana”? Podobne sformułowanie odnajdujemy już w Liście do Kościoła w Smyrnie (2,8-11), gdzie mowa o zniewadze wyrządzanej wspólnocie ,przez tych, którzy uważają siebie za Żydów, podczas gdy nie są nimi, lecz są synagogą Szatana” $(2,9)$. Zdaniem komentatorów wyrażenie „synagoga Szatana" odnosi się żydowskiej diaspory w Smyrnie i Filadelfii bądź jest to grupa judaizujących chrześcijan ${ }^{22}$ lub skażonych gnozą z elementami judaistycznymi (np. zwolennicy doketyzmu, którzy zaprzeczali prawdziwości śmierci i zmartwychwstania Jezusa, a mogli nazywać się Żydami, ponieważ byli przekonani, że w głoszonych poglądach inspirują się tradycjami ezoterycznymi, wywodzacymi się z pewnych form judaizmu $)^{23}$. Prawdopodobnie chodzi jednak o Żydów ${ }^{24}$, którzy oskarżali chrześcijan przed władzami rzymskimi o burzenie pewnego porządku państwowego, także z powodu odmowy składania ofiar o oddawania czci boskiej cezarowi. W ten sposób Żydzi w Smyrnie i Filadelfii byli postrzegani jako narzędzie Szatana w walce z chrześcijanami, bardziej lub mniej świadomie sami stawali się ofiarami machinacji szatańskich ${ }^{25}$, stąd określnie ich jako „synagoga Szatana”.

Jezus zapowiada, że przeciwnicy chrześcijan będą musieli uznać wspólnotę Kościoła „będą się tobie kłaniać do stóp” oraz rozpoznać charakterystyczną więź

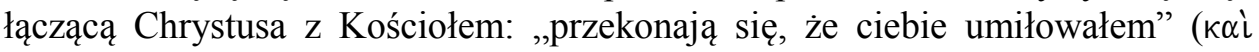

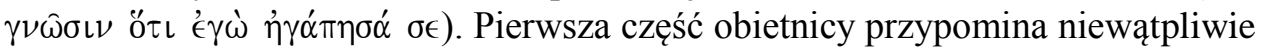
tradycje starotestamentowe, w których prorocy w podobny sposób zapowiadali przyjście pogan i oddanie pokłonu Izraelowi i Bogu Jedynemu (Iz 54,14; 49,23;

${ }^{21}$ P. O s t a ń s k i: Objawienie, dz. cyt. s. 118 .

${ }^{22}$ Zob. F. S i e g: Apokalips, dz. cyt. s. 125.

${ }^{23}$ Zob. D. K o t e c k i, Duch Święty, dz. cyt. s. 94-99.

${ }^{24}$ Zob. M. K a r c z e w s k i: Szatan w Apokalipsie św. Jana. Olsztyn 2013 s. 14-15.

${ }^{25}$ Zob. M. M a ri no: Custodire la Parola. Il verbo $\tau \eta € \epsilon \hat{\nu} \nu$ nell'Apocalisse alla luce della tradizione giovannea. Bologna 2003 s. 83. 
60,14; Za 8,22-23). W ten sposób zostaje podkreślona także wszechmoc Boga, który w swoim nieskończonym miłosierdziu doprowadza wszystkich do poznania prawdy. Jeśli w Starym Testamencie zapowiedzi odnosiły się do Izraela, a teraz te same proroctwa dotyczą Kościoła, to myśl jest oczywista: Kościół jest kontynuacją Izraela, a zatem także spadkobiercą miłości Boga do swojego ludu. Możemy tutaj widzieć aluzję do Iz 43,4, gdzie Bóg deklaruje swojemu ludowi: „Jesteś dla mnie cenny, otoczyłem cię chwałą i obdarzyłem miłością, dlatego ziemie zamienię na ciebie i ludy oddam za twoje życie".

W uznaniu autorytetu i prymatu wspólnoty Kościoła istotnym elementem staje się możliwość rozpoznania miłości Chrystusa, którą nieustannie darzy swoich wyznawców. Tekst nie precyzuje jednoznacznie, w jaki sposób będzie to możliwe i jak się to dokona. W sformułowaniu o oddaniu pokłonu do stóp nie chodzi o upokorzenie przeciwników chrześcijan, ale raczej Chrystus zapowiada niezwykłą skuteczność głoszenia Słowa Bożego. Tak jak kiedyś Filadelfia była sprawnym narzędziem propagowania kultury greckiej, tak teraz analogicznie pozostanie „otwartymi drzwiami, których nikt nie może zamknąć” $(3,8)$, a przez które będzie promieniowała wiarą i zapraszała do wejścia zarówno pogan i żydów, bo wszystkich, bez żadnego wyjątku, umiłował Bóg, co potwierdził w osobie i dziele Jezusa Chrystusa. Można zatem powiedzieć, że miłość Chrystusa niejako stanie się jawna i oczywista, nawet dla przeciwników, dzięki otwartości wspólnoty Jego wyznawców. Co więcej, miłość Chrystusa zobowiązuje właśnie do takiej postawy, bo ma ona ważny wymiar ewangelizacyjny. I nie chodzi tutaj tylko i wyłącznie o teoretyczne głoszenie miłości Chrystusowej, nawet poprzez wierne przepowiadanie słowa Bożego, które tę miłość zwiastuje, ale o praktyczne ukazanie sposobem życia i postępowania, że miłość Chrystusa wyraża się w sposobie życia i konkretnych czynach miłości. Jezus zna czyny wspólnoty w Filadelfii i dlatego jest pewien, że dzięki zaangażowaniu w przepowiadanie Słowa i wierności duchowi Ewangelii inni będą mogli rozpoznać i a przede wszystkim doświadczyć (,przekonać się") tej samej miłości we wspólnocie Jego wyznawców.

\section{III. »Tych, których kocham, napominam i wychowuję« $(3,19)$}

Kolejny interesujący nas tekst znajduje się w obrębie ostatniego z siedmiu listów Apokalipsy, którym jest List do Kościoła w Laodycei (3,14-22). Miasto to było bardzo znane w Azji Mniejszeje ${ }^{26}$, gdyż znajdowało się w południowowschodniej części Frygii, na skrzyżowaniu dwóch bardzo ważnych szlaków ko-

${ }^{26}$ Zob. R. T k a c z: Listy, dz. cyt. s. 349-359; D. K o t e c k i: „List do Kościoła w Laodycei” (Ap 3,14-21) w świetle hermeneutycznego klucza objawieniowo-liturgicznego. W: Credidimus caritati. Księga pamiatkowa dedykowana księżom profesorom Ryszardowi Figlowi $i$ Tadeuszowi Haneltowi w 70. rocznice urodzin. Red. M. O l c z y k, P. P o d e s z w a. Gniezno 2010 s. 246. 
munikacyjno-handlowych: z Efezu w głąb kontynentu i z Pergamonu do Attalei. W I w. przed Chr. Laodycea stała się jednym z najważniejszych miast Azji Mniejszej i to głównie ze względu na swoje bogactwo. Leżała bowiem na żyznej i urodzajnej równinie, gdzie mogło rozwijać się rolnictwo, zwłaszcza hodowla owiec (droga odzież produkowana $\mathrm{z}$ czarnej wełny była jednym z najważniejszych produktów eksportowych). Laodycea była dumna ze swojej bankowości, przemysłu tekstylnego oraz szkoły medycznej ${ }^{27}$. Nie wiadomo dokładnie, kto założył gminę chrześcijańską w Laodycei. Być może wspólnota powstała jako owoc pracy misyjnej czy też kontaktów nawiązanych ze św. Pawłem w czasie jego dwuletniego pobytu w Efezie (por. Dz 19,10). Wspólnota ta pozostawała w ścisłej relacji z tą w Kolosach, co można wywnioskować z ilości wzmianek odnoszących się do Laodycei w Kol (2,1; 4,13.15.16bis).

List rozpoczyna się od charakterystycznej autoprezentacji Chrystusa zmartwychwstałego, który nazywa siebie „Amen” oraz ,wiernym i prawdomównym Świadkiem, początkiem Bożego stworzenia" $(3,14)$. Zna On czyny wspólnoty, która odeszła od pierwotnego żaru duchowego i stała się „letnia” $(3,15)$. Dlatego Chrystus wzywa do odnowienia wiary i zaangażowania, bo mierna postawa Jego wyznawców przyprawia Go o mdłości $(3,16)$. Został tutaj użyty bardzo sugestywny obraz zaczerpnięty z życia codziennego mieszkańców Laodycei. Niedaleko miasta znajdowały się bowiem gorące źródła. Spożywanie wody gorącej czy zimnej nie powodowało żadnych przykrych skutków dla człowieka, natomiast picie tej samej wody w temperaturze letniej wywoływało mdłości i torsje. Stąd Jezus wzywa wspólnotę, aby była „zimna albo gorąca”, bo jeśli pozostanie letnia, to ją „wyrzuci, wypluje” (dosłownie: „Zwymiotuje”) ze swoich ust $(3,16)$.

Następne stwierdzenia pozwalają zrozumieć na czym polega owa letniość chrześcijan w Laodycei. Uważają się za „bogatych”, sytych i samowystarczalnych, bo bardzo polegają na tym, co posiadają $(3,17)$. Tymczasem taka postawa objawia ich prawdziwy stan ,godny pożałowania”, gdyż w rzeczywistością wspólnota w Laodycei okazuje się „biedakiem ślepym i nagim” $(3,17)$, któremu Jezus radzi nabycie u Niego trzech rzeczy, pozwalających na odnowienie życia religijnego zgodnie z wymogami Chrystusa ${ }^{28}$. Najpierw ma to być ,złoto oczyszczone w ogniu" $(3,18)$, które symbolizuje uczestnictwo w życiu samego Boga. Jak słusznie zauważa ks. Kotecki: Chrześcijanie z Laodycei sa zaproszeni, aby przejść od sytuacji Babilonii - Wielkiej Nierzadnicy, odzianej między innymi w złoto, purpure i bisior (por. Ap 17,4; 18,6), która symbolizuje system życia czy wspótżycie ludzkie nastawione calkowicie na konsumpcję i przez to zamknięte na Boga, czy transcendentny wymiar życia, do sytuacji Jerozolimy Nowej. Ztoto może być kupione jedynie od Jezusa (para emou). Ono należy do samego Chry-

\footnotetext{
${ }^{27}$ Zob. P. O s t a ń s k i: Objawienie, dz. cyt. s. 126.

${ }^{28}$ Zob. F. S i e g: Apokalipsa, dz. cyt. s. 139.
} 
stusa, ono Go wyraża: jego miłość, słowo, życie. Sam Jezus jest prawdziwym bogactwem, on daje Kościołowi wszystko, czego jemu brakuje. Człowiek może czynić najróżniejsze wysitki natury ekonomicznej i pozostanie biednym, godnym pożałowania. To jest sytuacja Kościoła w Laodycei, który, może nie do końca świadomie, znalazt się na pozycji Wielkiej Nierzadnicy ${ }^{29}$. Po drugie, chrześcijanie z Laodycei mają nabyć u Jezusa „białą szatę”, aby „nie ujawniła się haniebna nagość" $(3,18)$. Biała szata symbolizuje tutaj przyobleczenie się w Jezusa zmartwychwstałego. Jest strojem zbawionych $(6,11 ; 7,9.14)$, którzy wybielili ją we krwi Baranka $(7,14)$, to jest dzięki aktywnej wspótpracy z taska Chrystusa, która wypływa w tajemniczy sposób z całego Misterium Paschalnego, z całej witalności Zmartwychwstałego ${ }^{30}$. Na koniec Jezus radzi wspólnocie zakupić także balsamu (maści) dla namaszczenia oczu, aby przejrzeć $(3,18)$. Zdaniem U. Vanniego chodzi tutaj o samego Ducha Świętego, który uzdalnia do pełniejszego poznania (,zobaczenia”) tajemnicy Chrystusa ${ }^{31}$. Niewątpliwie kontekst wskazuje jednoznacznie, że chodzi o to, aby wspólnota przestała interesować się wyłącznie sobą, a spojrzała na Chrystusa i Jego relację do Kościoła, czego wymownym potwierdzeniem jest następne zdanie.

Zmartwychwstały Pan deklaruje: „Ja wszystkich, których kocham, napomi-

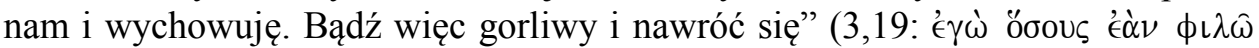

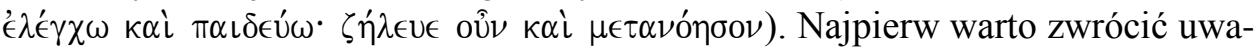
gę, że zdanie to rozpoczyna się od zaimka osobowego „ja”, który oczywiście odnosi się do Jezusa. Dzięki tej emfazie to właśnie On staje na pierwszym miejscu, jest najważniejszy. Cała uwaga wspólnoty ma być skoncentrowana wyłącznie na Jezusie.

Najważniejsze w kontekście naszych rozważań jest to, że w pierwszym rzędzie relacja Chrystusa do wspólnoty została opisana przez czasownik „miłować”, wyrażający miłość małżeńską i oblubieńczą. Komentatorzy zwracają często uwagę, że być może słowa te są aluzją do wypowiedzi z Prz 3,11-12: „Upomnieniem Pańskim nie gardź, mój synu, nie odrzucaj ze wstrętem strofowania. Bowiem karci Pan, kogo miłuje, jak ojciec syna, którego lubi”. Nawet jeśli kontekst jest podobny, bo wskazuje na relację Boga do swojego ludu, to jednak w Apokalipsie akcent położony został nie na miłość ojcowską (,jak ojciec syna”), ale na oblubieńczą miłość Jezusa do swojego Kościoła. To ona jest siłą napędową wszelkich działań podejmowanych przez Jezusa w odniesieniu do wspólnoty. Zostają one wyrażone przy pomocy dwóch kolejnych czasowników: „napominać” i „wychowywać”, które charakteryzują aktywność pedagogiczną Jezusa. To, co jest niezwykle ważne, że obie czynności są inspirowane nie gniewem czy

\footnotetext{
${ }^{29}$ D. K o t e c k i: , List do Kościoła w Laodycei”, dz. cyt. s. 257.

${ }^{30}$ Tamże.

${ }^{31}$ Zob. U. V a n n i: L'Apocalisse. Ermeneutica, esegesi, teologia. Bologna 1991 s. 155.
} 
chęcią wymierzenie sprawiedliwej kary, ale bezgraniczną miłością do człowieka. Jednocześnie jest to wielkie słowo nadziei, gdyż Kościół może mieć pewność, że nawet mimo złej kondycji duchowej, jak w przypadku wspólnoty w Laodycei, pozostaje zawsze wspólnotą umiłowaną przez Jezusa. To właśnie ta nieskończona miłość Zbawiciela sprawia, że Jezus nie może pozostać obojętny wobec letnich postaw swoich wyznawców. Dlatego nieustannie napomina i poucza, pokazuje drogę oraz konkretne środki, aby wspólnota Jego wyznawców mogła się odnowić i żyć zgodnie z Jego oczekiwaniami. Osiągnieciu tego celu służy swoistego rodzaju rachunek sumienia, który Jezus proponuje Kościołowi ${ }^{32}$, wskazując poprzez swoje upomnienia, zwłaszcza na te sfery życia i działania Jego wyznawców, które domagają się korekty lub całkowitej przemiany. Twarde czasem słowa i surowe wyrzuty (jak w przypadku Laodycei) nie są nigdy sprzeczne z miłością Chrystusa, ale są raczej wyrazem głębokiej troski o wspólnotę, która potrzebuje prawdy o swoim życiu i postępowaniu, aby w jej świetle mogła odpowiedzieć na pytanie, w jakim stopniu pozostaje wierna Chrystusowi i Jego Ewangelii.

Kościół w Laodycei zostaje wezwany do odnowienia zapału, gorliwości, a ostatecznie nawrócenia. Stąd słyszy od Zmartwychwstałego „bądź więc gorliwy i nawróć się” $(3,19)$. Użyty tutaj czasownik „bądź gorliwy” wskazuje na gorliwość, będącą wyrazem miłości wrażliwej, płomiennej, która jest niczym innym jak odpowiedzią wspólnoty na miłość samego Chrystusa która jest namiętna, pełna zapału i zaangażowania. Jest zatem niezwykle ważne, aby Kościół nie tylko był świadomy tej miłości Chrystusa, ale nieustannie ją odkrywał, bo warunkuje i umożliwia ona prawdziwe nawrócenie. Jak zauważa trafnie ks. Kotecki: To odkrywanie miłości Chrystusa w Jego konkretnym działaniu na rzecz wspólnoty zebranej na liturgii, jest niczym innym jak nawróceniem. Z kontekstu wynika, że na pierwszym miejscu wcale nie chodzi tutaj o nawrócenie $w$ sensie moralnym (poprawienie swojego postępowania), ale nawrócenie, które jest, zgodnie z etymologia słowa metanoia (,,myślenie ponad”), wzniesieniem się ponad swój wtasny sposób myślenia. W przypadku chrześcijan z Laodycei chodzi o przejście od skupienia się na samych sobie (samowystarczalność, samozbawienie) do skupienia się na Jezusie, z intencja brania od niego tego wszystkiego, czego wspólnota naprawde potrzebuje do życia duchowego. Nawrócenie jest rezultatem odkrycia namiętnej, statej mitości Chrystusa do swego Kościola ${ }^{33}$. Z pewnością nie jest to akt jednorazowy, ale trwający w czasie, to znaczy chodzi o nieustanne nawracanie się, które jest codziennym odkrywaniem nieskończonej miłości Chrystusa do swego Kościoła.

${ }^{32}$ Zob. B. G i e m z a: Rachunek sumienia Kościoła w świetle Apokalipsy. Kraków 2010. Autor wykorzystuje zwłaszcza pierwszą cześć Księgi, którą stanowi siedem Listów do Kościołów Apokalipsy.

${ }^{33}$ D. K o t e c k i: „List do Kościoła w Laodycei”, dz. cyt. s. 259. 
Kolejne sformułowanie, które odnajdujemy w analizowanym Liście, potwierdza to stałe zatroskanie Chrystusa o wspólnotę: „Oto stanąłem u drzwi i pukam. Kto usłyszy mój głos o otworzy drzwi, przyjdę do niego i zasiądę z nim do wspólnej uczty". To właśnie miłość Jezusa sprawia, że przychodzi On do człowieka jak Oblubieniec do swojej Oblubienicy (Pnp 5,2). Co więcej, Jezus stanął u drzwi. Postawa stojąca wyraża w Apokalipsie prawdę o zmartwychwstaniu Jezusa (5,6: „Baranek stojący, jakby zabity”34), a użycie czasu perfectum wskazuje, że ta obecność Pana jest nieustanna, cierpliwa i wytrwała ${ }^{35}$. Wyraźnie wskazuje na to następna czynność wyrażona czasownikiem „pukać, kołatać” w czasie teraźniejszym. Obraz ten wyraża symbolicznie niezwykłą „taktykę” Chrystusa. Pisze ks. Ostański: Chrystus puka do ludzkiego serca i czeka. Czyż można bardziej przekonująco ukazać miłość Boga ku ludziom i zaproszenie do bliskości z soba? ${ }^{36}$. Bo faktycznie według Apokalipsy Chrystus cierpliwie czeka i wielokrotnie (czas teraźniejszy) dobija się do serca ludzkiego, aby człowiek otworzył swoje życie dla Niego. Jeśli to uczyni wówczas będzie możliwa wspólna uczta, która jest ostatecznie symbolem duchowej wspólnoty i jedności z Chrystusem. Zapowiada on jednocześnie nagrodę dla zwycięzcy, polegającą na pełnym uczestnictwie w Jego królowaniu i triumfie nad Szatanem: „zwycięzcy pozwolę zasiąść na mym tronie, jak i Ja po zwycięstwie zasiadłem z Moim Ojcem na Jego tronie" $(3,21)$.

\section{IV. »Miasto umilowane« $(20,9)$}

Jednym z istotnych idei Apokalipsy jest prawda o ostatecznej klęsce Szatana, która nastąpi po drugiej bitwie (20,7-10), jaką stoczy on z wyznawcami Jezusa. Według 20,2-3 Smok, jednoznacznie identyfikowany ze starodawnym Wężem, to znaczy Diabłem i Szatanem (podobnie w 12,9), został spętany i wrzucony do Czeluści na tysiąc lat, gdzie zamknięty oczekuje na ostateczny wyrok. W ten sposób działanie Szatana zostało ograniczone, ale jeszcze nie całkowicie wyeliminowane. Nie będzie mógł zwodzić ludzi podczas tysiącletniego królowania Chrystusa i Jego wyznawców $(20,4-6)^{37}$, których miłość Chrystusa uczyniła kapłanami Boga i kapłanami Chrystusa ${ }^{38}$. Chodzi tutaj o czas ziemskiej historii Kościoła, która dzięki nieustannie trwającej miłości Chrystusa oraz dziełu zbawienia naznaczona jest jakby niemocą (uwięzieniem) Szatana, gdyż wyznawcy

\footnotetext{
${ }^{34}$ Zob. P. P o d e s z w a: Paschalna pamięć, dz. cyt. s. 235-238.

${ }^{35}$ Zob. F. S i e g: Apokalipsa, dz. cyt. s. 140.

${ }^{36} \mathrm{P}$. O s t a ń s k i: Objawienie, dz. cyt. s. 131.

${ }^{37} \mathrm{Na}$ temat interpretacji tysiąca lat, zob. J. N o w i ń s k a: Motyw wojny dobra ze złem w Apokalipsie św. Jana. Warszawa 2006 s. 257.

${ }^{38}$ Zob. W. P o p i e le w s k i: Zbawieni przez miłość Baranka (Ap 1,5b-6). „Verbum Vitae”. T. 1: 2002 s. $196-197$.
} 
Jezusa, dzięki zbawczej krwi Baranka są królestwem i kapłanami, królującymi na ziemi $(5,10)$.

Kiedy jednak upłynie tysiąc lat, zgodnie $\mathrm{z}$ zapowiedzią wyrażoną już w 20,3, Szatan zostanie uwolniony na krótko, aby stoczyć kolejną walkę z wyznawcami Boga. Jeśli tysiącletnie królowanie Jezusa i Jego wyznawców oznacza czas ziemskiej historii Kościoła to uwolnienie Szatana z Czeluści wskazuje na ostatnie dni owej historii, które poprzedzą paruzję. Zgodnie $\mathrm{z}$ tradycją biblijną będą charakteryzowały się one zaciętym atakiem Złego (Mt 24,21-22; 2 Tes 2,34). Wyswobodzony $\mathrm{z}$ więzienia $(20,7)$ przez Boga (passivum divinum) Diabeł rozpocznie od zwodzenia narodów Goga i Magoga, przygotowując je jako swoich sojuszników do rozstrzygającej walki. Został już pozbawiony swoich popleczników $(19,20)$ i dlatego wobec swej bezsilności oraz samotności działania będzie szukał nowych sprzymierzeńców w finałowym starciu. Dość zagadkowe określenie „narody Goga i Magoga” ${ }^{\text {"3 }}$, odczytywane w kontekście proroctw Księgi Ezechiela (Ez 38-39) oznaczają wszelkie siły przeciwne Bogu i Barankowi. Pod wodzą Szatana otoczą one „obóz świętych i miasto umiłowane” (20,9:

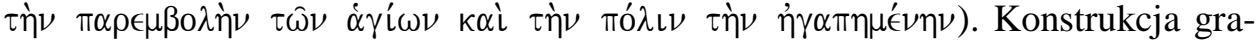
matyczna jasno wskazuje, że mamy tutaj do czynienia z paralelizmem synonimicznym $^{40}$, stąd oba określenia odnoszą się do ziemskiego Kościoła rozumianego najpierw jako wspólnota świętych, to znaczy tych, którzy przynależą do Boga i zanoszą do Niego swoje modlitwy $(5,8 ; 8,3.4)$, w wojnie dobra ze złem są przeciwnikami Bestii $(13,7)$, charakteryzują się wiarą i wytrwałością $(13,10)$, strzegą przykazań i wiary w Jezusa $(14,12)$ oraz zostają zabici przez Bestię $(16,6)$, a Nierządnica jest pijana ich krwią $(17,6)$. Jak zauważa J. Nowińska, obóz świętych - jako formacja wojskowa - na co wskazuje kontekst - świadczy o fakcie trwajacej jednak ciagle wojny dobra ze złem ${ }^{41}$.

Drugie określenie Kościoła to „miasto umiłowane”. W kontekście naszych rozważań jest jasne, że wspólnota Kościoła może zostać określona w taki sposób, gdyż istnieje i jest podtrzymywana dzięki miłości Chrystusa. Wyrażenie „miasto umiłowane" jest niewątpliwie nawiązaniem do Jerozolimy, co jasno zostaje już sformułowane przez Syr 24,11, gdzie Mądrość stwierdza, że Bóg osadził ją w „swoim umiłowanym mieście, w Jerozolimie umieścił” jej władzę. Jeśli Kościół nazwany jest jak Jerozolima ,umiłowanym miastem” to w ten sposób mamy wyrażaną także ideę ciągłości między Izraelem i Kościołem. Pewne światło na rozumienie wyrażenia „miasto umiłowane” rzuca także zestawienie z 21,9, gdzie wizjoner otrzymuje propozycję ujrzenia Małżonki Baranka, którą okazuje

\footnotetext{
${ }^{39}$ Zob. J. N o w iń s k a: Motyw, dz. cyt. s. 260-262.

${ }^{40}$ Zob. M. W o j c i e c h o w s k i: Apokalipsa świętego Jana. Częstochowa 2012 s. 367.

${ }^{41}$ J. N o w iń s k a: Motyw, dz. cyt. s. 265; zdaniem M. W o j c i e c h o w s k i e g o, Apokalipsa, dz. cyt. s. 367 obóz może być nawiązaniem do obozów ludu Izraela na pustyni (Wj 29,14; Hbr 13,11), czyli do idealnego symbolu ludu Bożego.
} 
się Święte Miasto Jerozolima, schodzące z nieba od Boga $(21,10)$. Kościół rozpoznając się jako „umiłowane miasto” wyznaje wiarę $w$ miłość, która zbawia uwalnia do grzechów i czyni z Kościoła lud kapłański i królewski. Moca Paschalnego Misterium powstat Kościól, wspólnota Nowego Przymierza przeznaczona, by stać się Matżonka Baranka w eschatologicznych godach. Powstanie Kościoła było inicjatywa urzeczywistniona przez Chrystusa. Zrodzona we krwi Baranka jego Oblubienica będzie poprzez dzieje przygotowywana do wejścia na gody, by u kresu czasów rozblysnąć jako Miasto Święte, Jeruzalem Nowe, przystrojone jak Oblubienica zdobna w klejnoty dla swego męża $a^{42}$.

Kościół będący miastem umiłowanym przez Boga i zrodzony we krwi Baranka jest pewien, że On stanie w jego obronie, ujmie się za nim i pokona ostatecznie wszelkie zagrażające mu zło. Apokalipsa zapowiada, że ogień z nieba spadnie i pochłonie napastników $(20,9)$, a Diabel, który zwodzi i oszukuje, zostanie wrzucony przez Boga do ognistego jeziora siarki, podobnie jak wcześniej Bestia i Fałszywy Prorok $(20,10)$ i będzie to równoznaczne z wiecznym potępieniem Szatana oraz definitywnym pozbawieniem go wszelkiej możliwości działania $^{43}$. To ostateczne pokonanie zła jest możliwe dzięki zwycięskiej mocy Chrystusa - Baranka ${ }^{44}$. Wspólnota Kościoła żyje nieustannie ową pewnością definitywnego zwycięstwa dobra i dlatego nie poddaje się nigdy w walce z Szatanem, która rozgrywa się w jej ziemskiej historii.

\section{Podsumowanie}

Analizowane teksty zaczerpnięte $\mathrm{z}$ Apokalipsy Janowej jednoznacznie wskazują, że miłość Boga objawiona w Jezusie i urzeczywistnione w Jego dziele zbawczym, zwłaszcza misterium paschalnym, jest fundamentem istnienia wspólnoty Jego wyznawców. Kościół zrodzony z miłości Chrystusa ma świadomość, że miłość ta określa tożsamość wspólnoty, a liturgia staje się uprzywilejowanym miejscem celebracji tajemnicy Chrystusowej miłości (1,5), dzięki której chrześcijanie, oczyszczeni z grzechów i pojednani z Bogiem przez krew ukrzyżowanego i zmartwychwstałego Baranka, stają się kapłanami i królują razem z Jezusem, mając udział w Jego ostatecznym zwycięstwie. Jak zauważa papież Franciszek: Pierwsza prawda Kościoła jest miłość Chrystusa. Tejże mitości, która zmierza aż do przebaczenia i do dania siebie samego, Kościót czyni się stuga i pośrednikiem wobec ludzi. Stąd też tam, gdzie Kościół jest obecny, musi się też zaznaczyć miło-

${ }^{42}$ W. P o p i e le w s k i: Zbawieni, dz. cyt. s. 197.

${ }^{43}$ Zob. M. K a r c z e w s k i: Szatan, dz. cyt. s. 21-23.

${ }^{44}$ D. K o t e c k i: Jezus, dz. cyt. s. 426 słusznie zauważa, że w kontekście całego sądu orzeczenia $\mathrm{w}$ stronie biernej, których podmiotem jest Bóg (passivum divinum), nabieraja kolorytu chrystologicznego. To nikt inny jak boski Chrystus dokonuje ostatecznego sadu nad siłami zła. $W$ jeziorze siarki $i$ ognia znajduja się przeciwnicy Boga i Baranka, którzy nie weszli do Nowej Jerozolimy. 
sierdzie Ojca. W naszych parafiach, w naszych wspólnotach, w stowarzyszeniach, w ruchach, gdziekolwiek sa chrześcijanie, każdy powinien tam odnaleźć oazę miłosierdzia ${ }^{45}$. Skoro Kościół, jak pisze papież, czyni się sługa i pośrednikiem miłości Chrystusa wobec świata, to miłość ta powinna przenikać wszelkie formy i przejawy życia i działalności kościelnej, aby - jak przypomina nam Apokalipsa w 3,9 - świat mógł przekonać się o niej, to znaczy niejako „zobaczyć”, jak bardzo Jezus umiłował swój Kościół. Chodzi zatem o autentyczne i wiarygodne świadectwo miłości Chrystusa do Kościoła i Kościoła do Chrystusa, możliwe wyłącznie dzięki posłuszeństwu Jezusowi, który swoje „umiłowane miasto $(20,9)$, to jest Kościół, „napomina i wychowuje” $(3,19)$, wzywając do gorliwości i ciągłego nawracania się.

Słuchając głosu Zmartwychwstałego, który jako „Miłujący” nie przestaje powtarzać, że nas kocha i że chce dzielić z nami swoje życie [...], kontemplujac oblicze Chrystusa, Kościót jako pierwszy jest wezwany do tego, aby stat się świadkiem miłosierdzia, wyznając je i żyjac nim jako centrum objawienia Jezusa Chrystusa ${ }^{46}$. Wierne zachowywanie i celebrowanie, zwłaszcza w liturgii, pamięci o nieskończonej miłości Jezusa do swojego Kościoła czyni ze wspólnoty wyznawców skuteczne narzędzie Bożego miłosierdzia, przebaczenia, wsparcia, pomocy, miłości $i^{47}$. Wtedy Kościół nie zmęczy się nigdy ofiarowywaniem miłosierdzia i będzie zawsze cierpliwy w umacnianiu i przebaczaniu ${ }^{48}$, stając się jednocześnie $\mathrm{w}$ imieniu świata głosem wołającym $z$ ufnościa $i$ bez ustanku ${ }^{49}$, aby Bóg wspomniał na swoje miłosierdzie, które trwa na wieki (zob. Ps 25,6).

\section{BIBLIOGRAFIA}

Franciszek: Misericordiae vultus. Wrocław 2015.

Giemza B.: Rachunek sumienia Kościoła w świetle Apokalipsy. Kraków 2010.

Janus E.: Grzechy Kościolów Apokalipsy i Jezusowe sposoby ich przezwyciężenia (Ap 2-3). Kraków 2013.

Karczewski M.: Szatan w Apokalipsie św. Jana. Olsztyn 2013.

Kotecki D.: Duch Święty w zgromadzeniu liturgicznym w świetle Apokalipsy św. Jana. Warszawa 2006.

Kotecki D.: Jezus a Bóg Izraela w Apokalipsie św. Jana. Torun 2013.

Kotecki D.: Kościót w świetle Apokalipsy św. Jana. Częstochowa 2009.

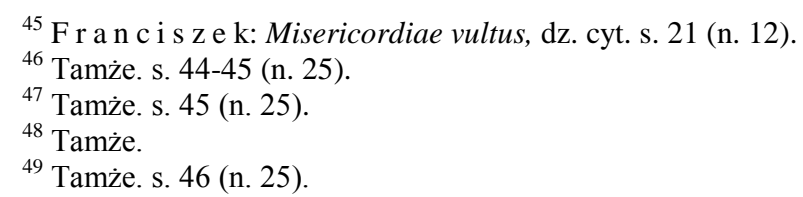


Kotecki D.: „List do Kościoła w Laodycei” (Ap 3,14-21) w świetle hermeneutycznego klucza objawieniowo-liturgicznego. W: M. Olczyk, P. Podeszwa (red.), Credidimus caritati. Księga pamiątkowa dedykowana księżom profesorom Ryszardowi Figlowi i Tadeuszowi Haneltowi $w$ 70. rocznice urodzin. Pod redakcją M. Olczyka, P. Podeszwy. Gniezno 2010 s. 239-263.

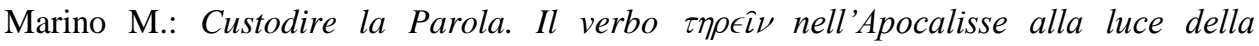
tradizione giovannea. Bologna 2003.

Mędala S.: Ewangelia wedtug świętego Jana. cz. II. Częstochowa 2010.

Nowińska J.: Motyw wojny dobra ze złem w Apokalipsie św. Jana. Warszawa 2006.

Ostański P.: Objawienie Jezusa Chrystusa. Praktyczny komentarz do Apokalipsy. Ząbki 2005.

Podeszwa P.: Doksologie Apokalipsy jako model modlitwy uwielbienia, „Verbum Vitae”. T. 22: 2012 s. 155-184.

Podeszwa P.: Paschalna pamięć o Jezusie. Studium egzegetyczno-teologiczne wyrażenia

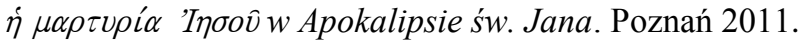

Podeszwa P.: Wspólnota Kościoła w świetle Apokalipsy św. Jana. W: Mowa światyni. Pod redakcją R. Dublańskiego. Wrocław 2012 s. 55-69.

Podeszwa P.: Wyprali swoje szaty $i$ wybielili je we krwi Baranka (Ap 7,14). Chrzest wedlug Apokalipsy świętego Jana. „Studia Bydgoskie”. T. 7: 2013 s. 33-54.

Popielewski W.: Błogosławieni, którzy sa wezwani na ucztę godów Baranka (Ap 19,9). Kościół w Księdze Apokalipsy. „Verbum Vitae”. T. 6: 2004 s. 169-181.

Popielewski W.: Zbawieni przez miłość Baranka (Ap 1,5b-6). „Verbum Vitae”. T. 1: 2002 s. 185-198.

Sieg F.: Apokalipsa św. Jana. Listy do siedmiu Kościołów (Ap 1-3). Pelplin² 2009.

Talaga P.: L'amore a Cristo, fondamento del ministero pastorale di Pietro nel Vangelo secondo Giovanni (21,15-23). Dissertatio ad Lauream in Facultate S. Theologiae apud Pontificiam Universitatem S. Thomae in Urbe. Roma 2003.

Tkacz R.: Listy do siedmiu Kościołów (Ap 2,1-3,22). Studium historyczno-egzegetyczne. Warszawa 2003.

Vanni U.: L'Apocalisse. Ermeneutica, esegesi, teologia. Bologna 1991.

Wojciechowski M.: Apokalipsa świętego Jana. Częstochowa 2012.

\section{ABSTRACT \\ »To him who loves us« (Revelation 1:5)}

Christ's love to the Church in the light of selected texts from the Apocalypse of John

I propose in the present article a reflection upon the mystery of God's love, revealed and materialized in Jesus Christ, which directly relates to the community of the Church. The analyzed texts have been taken from the last book of the New Testament. One of the essential features of ecclesiology in the Apocalypse is a conviction that the Church is a community begotten from Jesus' love, invariably upheld, enhanced and led through Christ's love. I have chosen texts from the Apocalypse which explicitly refer to Jesus' love to the Church and express this idea by means of two characteristic verbs of John's tradition, namely $\dot{\alpha} \gamma \alpha \pi \alpha^{\prime} \omega$ and $\phi\left\llcorner\lambda \lambda^{\prime} \omega\right.$. Although the said verbs are not often employed in the Apocalypse (four times: 1:5; 3:9; 12:11;20:9 and two times: $3: 19 ; 22: 15$ respectively), they are, however, mostly used in passages which describe a relationship between 
Christ and the community of the Church $(1: 5 ; 3: 9-19 ; 20: 9)$. During the liturgy, the Church worships Jesus, whose love is the foundation for everything (1:5): it is expressed through deliverance from sin, a sacrifice of one's own life and man's participation in Christ's victory and reign. The Church is obliged to show the world a clear testimony to love (3:9). It is being incessantly admonished and brought up by Christ, called up to renew zeal and conversion (3:19). As "the camp of the saints and beloved city" (20:9), the Church actively participates in the battle against evil and, supported by the loving God and Lamb, it lives on assured of Christ's ultimate victory.

Key words: Apocalypse, ecclesiology, love, Lamb, paschal mystery, beloved city, the camp of the saints, battle against evil, victory.

Słowa kluczowe: Apokalipsa, eklezjologia, miłość, Baranek, misterium paschalne, miasto umiłowane, obóz świętych, walka ze złem, zwycięstwo. 